\title{
To the question of old beleivers'faith in the Russian society at the turn of the XIX-XX centuries (researcher's view of A. S. Prugavin)
}

\author{
Natalya Kuznetsova * \\ Petrozavodsk State University, 185910, Petrozavodsk, Russia
}

\begin{abstract}
The article analyzes the views of the religiosity researcher - A. S. Prugavin on the Old Believers as part of society in the Russian Empire at the turn of the XIX-XX centuries. Data from the works of a religious scholar are given, unpublished materials identified by the author in the Russian State Archive of Literature and Arts (RSALA) in Prugavin's personal fund are analyzed. A comprehensive analysis of the researcher's materials allows us to note that Prugavin set himself broad tasks and used an integrated approach for research. He sought not only to understand the religious life of the Old Believers from within, but also to systematize the ways of studying this phenomenon in Russian society, classify the rumors in this social group, and determine the significance of the Old Believers for the country. Prugavin polemicized both with representatives of the Russian Orthodox Church (ROC), whose view of the Old Believers remained sharply negative, and with representatives of the authorities who perceived the Old Believers as an element heterogeneous and dangerous to society. The author concludes that, as a researcher of the religious issue in Russia, Prugavin, thanks to the global approach to work, was able to make as deep as possible an analysis of the Old Believer issue of interest to him. The religious scholar came to the conclusion that, despite the propaganda of the Russian Orthodox Church and the official authorities, the Old Believers should not be included in the category of "dangerous, alien element" for Russian society. Despite all the dissimilarity of the Old Believers to the traditional Orthodox population of Russia and the difficulty in their relations with the state, the Old Believers were one of the most educated and thinking sections of the country's population.
\end{abstract}

\section{Introduction}

Russian society at the turn of the XIX-XX centuries was a multinational society, in which adherents of various religious faiths coexisted. Rises in the spread of religious movements that distinguished themselves from the Russian Orthodox Church (ROC) on the territory of the empire have taken place throughout the history of the state. However, the turn of the century, as well as the beginning of the twentieth century, appeared most vividly on this issue. Legislative acts of the first decade of the twentieth century for the first time officially

*Corresponding author: foliage.07@mail.ru 
allowed the population adhering to other confessions getting choice of faith; all existing legislative restrictions were abolished.

The Old Believers, who during this period were a special spiritual community within the empire, were also legally endowed with the rights and freedoms in which they had previously been oppressed. However, as subsequent events showed, even after the legislative confirmation by the state of the right to own religion, the Old Believers in Russia continued to experience significant restrictions. The Russian Orthodox Church still perceived this religious group as an opposition force in the struggle for believers, and the state as a dangerous social element in society. This and many other acute questions concerning the Old Believers were raised in their studies by the famous Russian religious scholar Alexander Stepanovich Prugavin. His works on the study of the Old Believers in the Russian Empire are rightfully considered the most complex among his contemporaries.

\section{Wording of the problem}

The purpose of the article is to study the views of Prugavin on one of the most important religious groups in traditional Russian society in the Russian Empire at the turn of the XIXXX centuries. - Old Believers. The author of the article makes an attempt to reflect the global approach of the religious scholar to the indicated problem. This happens by comprehensively solving a certain range of research problems:

- selection and research of Prugavin's materials on the Old Believer issue, including unpublished sources stored in the researcher's personal archive in the Russian State Archives of History;

- based on an analysis of Prugavin's work, determining the place and role of the Old Believers for Russia in the specified period.

\section{Research Methods}

The study uses several key historical methods: comparative-historical and historicalgenetic. This makes it possible to identify markers of Prugavin's research interest in the problem under study, as well as to attempt to correlate the private research concept of a religious scholar with the existing context - the views that existed in Russian public thought.

\section{The main aspects of the research}

A.S. Prugavin in his works portrayed the Old Believers of the Russian Empire as a special religious group occupying a significant place in the history, culture, economy and public life of the state. This point indicates the relevance of his research studies today, as a number of modern researchers see in the Old Believers one of the foundations of Russian society (Tovbin K.M., Atorin R. Y., Kozhurin K. Y., 2018a; Tovbin K. M., Atorin R. Y., Kozhurin K. Y., 2018b). The researcher raised a significant number of problematic questions: how were the Old Believers divided into numerous groups and how did these social groups interact with the outside world (at the "man-nature" and "man-man" levels), which allowed the Old Believers to isolate themselves in a "different" environment.

Of particular interest to the researcher was the Old Believers at the frontier. For example, part of Prugavin's work touched on a rather isolated and remote region of the country - the European North. It was there - in the Arkhangelsk province - that the author began his acquaintance with the Old Believers, and later became interested in the history of one of Old Belief largest centers - the Vygovsky Monastery. In considering this issue, the 
religious scholar was even able to obtain particularly valuable materials from another researcher who adhered to the Narodnik views, S. A. Priklonsky - data on the split in the north in the Olonets and Arkhangelsk provinces. The latter served for quite a long time as an official in the office of the Olonets Governor and had access to a large volume of documents on the Old Believers problem in the European North, including secret ones. These data, namely, the lists and the scheme of the Vygov priors, copies and originals of letters and reports about the Old Believers of the Vygo-Leksinsky community during the reign of Alexander I and Nicholas I of local officials to governors and governors in St. Petersburg - he transferred to Prugavin. Prugavin, on the basis of these securities, was given the opportunity to analyze the topic of relations between state power and the largest Old Believer center in the European North.

In general, Prugavin's views on the Russian Old Believers' faith were based on the ideology of Narodism, which the author adhered to, starting from the student period. At the turn of the 1860s - 1870s, Prugavin, who entered the Petrovsky Agricultural Academy in Moscow, was included in the activities of student secret societies of the two capitals of the empire. During this period, he first got acquainted with the idea of including "religious renegades" in the revolutionary activity, since the Old Believer issue became an integral part of the historical worldview of the Russian intelligentsia (Sazhin B. B., 2018).

Moreover, a certain transformation of the researcher's views occurred during his stay in exile in the Arkhangelsk province (1871-1879). Immediate stay on one of the empire frontiers, which became the site of Old Believer society concentration, in close proximity to the historical centers of the Old Believers-Bespopovites (Vyg and Topozersky Hermitage) allowed Prugavin to take a fresh look not only at the Old Believers themselves, but also at the whole research experience their research accumulated in Russia. A future well-known religious scholar then pointed out that "almost the entire resident population $<\ldots>$ consists of Old Believers" and that he took the opportunity to "personally get acquainted with representatives of different sects $<\ldots>$, visit their monasteries, study various manuscripts common among them" (Pashkov A.M., 2004, p. 341).

Thus, due to a special combination of life circumstances, it was precisely at the stage of the 1880 s that Prugavin came to the conclusion that there was insufficiency and lack of completeness and objectivity in studies of the Old Believers. The researcher devoted all his subsequent life to research on this topic.

The exile period of Prugavin was marked by the appearance of a number of his first journalistic works on the Old Believers, which raised particularly acute issues related to the attitude of local authorities to these believers, as well as to the understanding and acceptance of this social group by the local traditional society. Thus, in several issues of the "Golos" and "Nedelya" newspapers, the researcher uncovered an episode of the believers' struggle of the Ambur Old Believer Hermitage and Arkhangelsk officials (Sazhin B. B., Kuznetsova N. Yu., 2017). Immediately after his release, he submitted to the Imperial Russian Geographical Society a draft Program for collecting information about the Russian schism or sectarianism, which was ultimately published.

Interesting is Prugavin's research studying traditional Old Believers' practices. He himself even tried some. In this vein, one can consider his mentoring experience in relations with young researchers of religiosity. In particular, for several years, the religious scholar communicated and corresponded with E.V. Molostvova, becoming a reviewer of her book about Jehovah's Witnesses (N. Kuznetsova, I. N. Ruzhinskaya, 2016). This episode illustrates the fact that Prugavin not only set out to study special Old Believers' practices, but also adopted the most optimal moments and successfully applied them to life.

Another significant moment in the Old Believers' studies by Prugavin is the experience of studying the development of Old Belief historical memory in the European North and the influence of both on traditional peasant society and the activities of the Old Believers 
themselves. The author, in the end, emphasizes the importance of the Old Believer selfimmolations for creating the image of the territory, as well as the direct connection of the historical memory of all believers included in the society of the region. In addition, Prugavin emphasizes the similarity between the events in the regional history of both Orthodox and Old Believer communities. For example, the case of false mentors in the Old Believers and similar episodes observed with impostor priests in the Russian Orthodox Church (E. Suslova, 2017). Or the experience of economic activity of both Old Believer religious centers and monasteries of the Russian Orthodox Church (Suslova E. D., 2010; Suslova E. D., 2016). The religious scholar points out that the Old Believers living in difficult conditions could not help interacting with traditional northern society, and that the frontier left an imprint on building "human-nature" relations no less than "human-human" relations, like the representatives of the local peasantry (Chernyakova I.A., 2009).

The very concept of "schism" as a special phenomenon in Russian life, A. S. Prugavin defined for himself, not relying solely on the research of predecessors and contemporaries. He saw in this "the totality of all generally religious-ethical and religious-everyday protests and disagreements of the Russian people" (Prugavin A. S. 1905, S. 9), thus summarizing, in this term, both the Old Believers and all that existed in society sects. The traditionalism of the abundant social movements and their relationship with each other were also reflected in the author's research work. In particular, his several books and archival manuscripts contain attempts to derive a classification of religious movements in Russia.

\section{Conclusion}

A.S. Prugavin, a researcher and religious scholar became famous in the turn of the XIX-XX centuries at the Russian Empire level, chose the Old Believer issue in Russia as key topic for his research. Having studied a huge amount of materials of his predecessors and contemporaries on this issue, having established communication with the Old Believers themselves, the researcher gained some experience and could rightly conclude that the Old Believers should not be defined as the "original phenomenon of the spiritual life of the Russian people" neither by the intelligentsia, nor official authorities, nor the Russian Orthodox Church as an heterogeneous and dangerous social group for Russian society. Prugavin showed his contemporaries that the Old Believers, who managed to go through difficult trials and ordeals throughout the history of their group, did not lose their own identity and historical memory, could form the basis of the Russian people as the most thinking and developed part of it. The religious scholar also drew attention to the fact that it is precisely these movements in the future that will not only change the popular consciousness, but also provide an opportunity for rooting innovative ideas in the Russian people.

\section{Acknowledgements}

The study was carried out with the financial support of the Russian Federal Property Fund in the framework of the scientific project No. 18-39-00058 mol_a.

\section{References}

1. N.Y. Kuznetsova, I.N. Ruzhinskaya, The Old Believer tradition of mentoring as an example of a continuous educational tradition, Continuing Education: XXI Century, 4(16), 50-61 (2016). DOI: 10.15393 / j5.art.2016.3304. 
2. A.M. Pashkov, Unpublished manuscript by A.S. Prugavina about the persecution of the Vygov Old Believers under Nicholas I: an unknown episode of the Narodnik "schismatic", Old Believers in Russia (XVII - XX centuries), 3, 339-357 (2004).

3. A.S. Prugavin, Schism and sectarianism in Russian folk life (Printing house of I. D. Sytin, Moscow, 1905).

4. B.B. Sazhin, N.Yu. Kuznetsova, Persecution of the Ambur skete of Alexander Stepanovitch Prugavin, Bulletin of St. Petersburg University, 62(4), 807-816 (2017). DOI: 10.21638 / 11701 / spbu02.2017.408.

5. B.B. Sazhin, Religious persecution of the Old Believers as a factor in the internal colonization of Russia in the view of the Narodniks, The Light of Christ enlightens everyone: Almanac of the St. Philaret Orthodox Christian Institute, 27, 21-33 (2018).

6. E.D. Suslova, The clergy and laity of the Olonets Uyezd: the experience of the settlement of enslavement in the Shuisky graveyard in the middle of the XVII century, Bulletin of the Peoples' Friendship University of Russia, 4, 75-86 (2010).

7. E.D. Suslova, Karelian impostor priest in the face of church authorities in the first third of the 18th century, Bulletin of the Orthodox St. Tikhon Humanitarian University, 74, 63-79 (2017). DOI: 10.15382 / sturII201774.63-79.

8. E.D. Suslova, Fishing in the Assumption Murom Monastery in the first third of the 17th century Scientific Dialogue, 11 (59), 334-351 (2016).

9. K.M. Tovbin, R.Yu. Atorin, K.Ya. Kozhurin, Orthodox Old Believers as a variant of Russian civilization: the relevance of the study, Scientific notes of the Crimean Federal University named after V.I. Vernadsky, Philosophy, Political science, Cultural Studies, 4 (2), 38-45 (2018a).

10. K.M. Tovbin, R.Yu. Atorin, K.Ya. Kozhurin, Orthodox Old Believers as a variant of Russian civilization: research methodology, Bulletin of Slavic cultures, 49, 9-31 (2018b).

11. I.A. Chernyakova, Local peasant community of Karelia of the 19th century in the struggle for survival: strategy or intuition?, Russian History, 3, 216-226 (2009). 